\title{
Association of GSTM1, GSTT1 Genes Polymorphisms and Risk of Psoriasis in Thi Qar Province / Iraq
}

\author{
Ahmed Abdulhussein Kawen * \\ Hayder Hussein Jalood ** \\ * Department of Dermatology - College of Medicine - University of Thi Qar, Iraq \\ Department of Pharmacy- Mazaya University College, Iraq
} $* *$

\begin{abstract}
Psoriasis is a chronic inflammatory and proliferative skin disorder with a not entirely comprehended etiology. The aim of present study was to investigate the clinical features and estimate the association between null of GSTM1, GSTT1 genotypes and the development of psoriasis in Dhi Qar province. This study included 100 psoriasis patients and 100 healthy (mean age $29.08 \pm 16.46$ and $31.8 \pm 11.2$ respectively). Early onset was predominant $(71 \%)$ than the late onset (mean of age onset $24.97 \pm 15.6$ ). $51 \%$ of patients were males , $49 \%$ were females. Among cases $80 \%$ were non smoker, $20 \%$ were smoker. No significant between patient and control according to place of residence. Psoriasis vulgaris found in $65 \%$ of cases. Positive family history appear in $13 \%$ of patients. More of patients $(56 \%)$ were exposure to stress during lifestyle. 5\% patients were synchronized viral and bacterial infections. Analysis of GSTM1, GSTT1 genotype showed no statistically significant with psoriasis susceptibility $(\mathrm{OR}=0.56 ; 95 \%, \mathrm{CI}=0.32-0.99)$ and $(\mathrm{OR}=0.48 ; 95 \%, \mathrm{CI}=0.25-0.92)$. Also the combined effect of GSTM1/GSTT1 null genotypes were found no increased risk of psoriasis $(\mathrm{OR}=0.55 ; 95 \%, \mathrm{CI}=0.20-1.51)$.
\end{abstract}

Key words: Psoriasis, GSTs ,polymorphism, PCR.

\section{Introduction}

Psoriasis is a chronic inflammatory and proliferative skin disorder with a not entirely comprehended etiology [1]. It affects approximately $2 \%$ of the worldwide population [2]. Psoriasis can develop at any age, but the greater number of cases, $75 \%$ approximately, appear before the age of 40 years[3]. Although the precise causes of the disease remains unknown, The most important factors of etiology include genetic, environmental and immunologic factors. The genetic foundation of psoriasis is complex as multiple genes are contributed. The heritability of psoriasis has been evaluated to be $60 \%-90 \%$, which is 


\section{Email:utjmed@utq.edu.iq}

among the elevated of all multifactorial genetic disorders [4,5].

Family studies suggested that if together parents have psoriasis, the progeny have a $50 \%$ probability of developing the sickness. The risk of psoriasis reduce to $16 \%$ if only one parent has its. If neither parent is influenced but a child develops psoriasis then their relation have an $8 \%$ risk of developing the sickness. Women have a lower risk of transmitting psoriasis to offspring than men, which is probably due to feature of genomic [6]. Recently, the oxidative stress has been proposed as a risk factor of psoriasis development [7]. Oxidative stress is a disproportion between oxidants and antioxidants feasible the oxidants, bring about a disturbance of redox signaling and command and/or infinitesimal damage. The skin is a possible target for oxidative damage, as it is constantly exposed to ultraviolet radiation and another environmental stresses producing reactive oxygen species (ROS) [8]. ROS intermediate oxidative stress includes a large number of biological molecules which causes lipid peroxidation, DNA modulation, and excretion of inflammatory cytokines [9]. Under certain circumstances, practically all skin cells seem suitable expressing the empirical NOS isoform (NOS II). The NO• liberated subsequent ultraviolet radiation plays an important role in begin melanogenesis, erythema and immunosuppression [10]. A universal and incorporated antioxidant defense
Web Site: https://imed.utq.edu.iq

mechanism of skin is critical in protecting this organ from reactive oxygen species [11]. One essential line of defense is,a system of enzymes, made up of glutathione,peroxidase, superoxide,dismutase (SOD) and catalase (CAT) which decrease the concentration of the most harmful oxidants [12]. An important contribution to the aggregate antioxidants comes from antioxidant system in serum. Antioxidants can keep the epidermis from the foreign molecules that participate to epidermal toxicity and illness. Insufficiency of the antioxidant system can lead to a reduction in the aggregate antioxidant status of an individual [13]. However, reducing antioxidant protection or exceeding reactive oxygen species cause a condition known as a oxidative stress, leading to the pathogenesis of dermal disease and disorders [14].

The glutathione S-transferases (GSTs) are a super family of multigenes. They produce enzymes which can stimulate the coupling of glutathione to electrophilic substrates. These enzymes are contributed in the detoxification of together endogenous and exogenous electrophiles which can interact with cellular molecules such as DNA [15]. The family is possessed of eight isoforms of genes which include: alpha (GSTA) mu (GSTM) pi (GSTP ) theta (GSTT) tau (GSTZ) sigma (GSTS) omicron (GS TO) and kappa (GSTK) [16]. The greatest common various of the GSTM1 and GSTT1 genes is homozygous deletion (null genotype), 


\section{Email:utjmed@utq.edu.iq}

which has been related with the lack of enzyme activity and increased sensitivity to cytogenetic damage [17]. The GSTM1 is the genes located on chromosome 1p13.3 which coding the $\mathrm{mu}$ class of enzymes [18]. The GSTT1 genes located on chromosome $22 q 11.23$ coding the theta class of enzymes [19]. many studies showed the link between the lack of enzyme activity in GSTM1 and GSTT1 and the susceptibility to development various types of skin disease, such as vitiligo [20,21,22], systemic lupus erythematosus LE $[23,24]$. Few studies have looked to the associated between a null genotype of GSTM1,GSTT1 genes and the occurrence of psoriasis [25]. In this study, we concerned to define the influence of GSTM1 and GSTT1 null polymorphisms on the risk for psoriasis.

\section{Materials and Methods}

The current study was accomplished in the Cancer researches unit, Medical college of Thi-Qar university in cooperation with genetic laboratory in Mazaya . An aggregate of 200 people were incorporated into this review, out of these 100 were healthy controls and 100 were recently analyzed psoriasis patients matured between $<10$ to 60 years. Psoriasis patients group and control group were distributed according to the age, gender, smoking, place of residence, family history. About $2.5 \mathrm{ml}$ venous blood specimens were gathered into an EDTA vacutainer tubes and they kept in

\section{Web Site: https://imed.utq.edu.iq}

refrigerator till utilized for genomic DNA isolation.

\section{Amplification of GSTM1 and GSTT1 genes}

Whole DNA was extracted from white blood cell, by using $\mathrm{gSYNC}^{\mathrm{TM}} \mathrm{DNA}$ Mini kit. GSTM1 and GSTT1 genes were amplification by using a multiplex polymerase chain reaction (PCR ) in which albumin gene as an internal control was utilized. Forward and reverse primers of GSTM1 gene amplification were as follow: 5\GAG GAA CTC CCT GAA AAG CT A AAG-3/ and 5〉CTC AAA TAT ACG GTG GAG GTC AAG-3/ respectively. For GSTT1 gene: 5/-TTC CTT ACT GGT CCT CAC ATC TC-3\ and 5\TCA CCG GAT CAT GGC CAG CA3/ forward and reverse respectively, while regarding of albumin gene primers were: 5/GCC CTC TGC TAA CAA GTC CTAC -3/ (forward) and 5/GCC CTA AAA AGA AAA TCG CC A ATC -3/ (reverse).

PCR amplification was carried out with a total volume of $25 \mu \mathrm{l}$ with templet DNA $(5 \mu \mathrm{l})$, master mix $(5 \mu \mathrm{l})$, distal water $(9 \mu \mathrm{l})$ and $1 \mu \mathrm{l}$ of each primers of GSTM1, GSTT1 and albumin genes. PCR program was designed as followed an initial denaturation at $95^{\circ} \mathrm{C}$ for 5 minutes, followed by 35 cycles at $94^{\circ} \mathrm{C}$ of denaturation for 1 minute, $58^{\circ} \mathrm{C}$ of anneling for 1 minute, $72^{\circ} \mathrm{C}$ of extension for 1 minute and a last extension at $72^{\circ} \mathrm{C}$ for 10 minutes. PCR products were migrated 


\section{Email:utjmed@utq.edu.iq}

electrophoretically on a $2 \%$ agarose gel recolored with $0.5 \mu \mathrm{l}$ ethidium bromide. The GSTT1, GSTM1 and albumin genes appeared bands at 480 bp, $216 \mathrm{bp}$ and $350 \mathrm{bp}$ respectively. The presence of albumin gene without GSTT1 or GSTM1 genes refers to their deletion.

\section{Statistical Analysis}

Clinical features were analyzed as Mean $\pm \mathrm{SD}$ and chi-square test. $\mathrm{P}$ values $<0.05$ was considered as significant. Odd ratio (OR) test with 95\% confidence intervals $(95 \% \quad \mathrm{CI})$ was used to evaluate the significance relationship between GSTT1 and GSTM1 null genotypes and the psoriasis development. OR $<1.5$ was considered as significant.We have used the statistical version SPSS 17.

\section{Clinical Results}

\section{Web Site: https://imed.utq.edu.iq}

The mean age of psoriasis patients and control group was $29.08 \pm 16.46$ and $24.97 \pm 15.6$ respectively (table 1 ). $71 \%$ of patients had age of onset around the age of 30 years while $29 \%$ of cases had onset after the 30 years of age (table 2).

Out of 100 cases 51 (51\%) were males while rest 49 (49\%) were females (table 3). $20 \%$ of psoriasis group were smoker, while $80 \%$ were non smoker (table 4). Based on living, Majority of cases $58 \%$ were from urban areas (table 5). Psoriasis disease was classified as shown in Table 6. The most common type of psoriasis is vulgaris $(65 \%)$ followed by psoriasis scalp (15\%), palmo plantar (10\%), psoriasis Guttate (5\%) and Pustular (5\%). 13\% psoriasis patients are associated with the positive family history , $56 \%$ of patients are suffering from stress in their lifestyle. In the other hand, $5 \%$ of patients are associated with viral and bacterial infections (table 7).

Table 1 - Frequency distributions of patient group and control group according to ages

\begin{tabular}{|c|c|c|c|c|c|}
\hline \multirow{2}{*}{ Age (years) } & \multicolumn{2}{|c|}{ Cases $(\mathbf{n}=\mathbf{1 0 0})$} & \multicolumn{2}{|c|}{ Controls $(\mathbf{n = 1 0 0})$} & P \\
\cline { 2 - 6 } & $\mathrm{n}$ & $\%$ & $\mathrm{n}$ & $\%$ & $\begin{array}{c}\text { valu } \\
\mathbf{e}\end{array}$ \\
\hline $\mathbf{1 1 0}$ & 20 & $20 \%$ & 11 & $11 \%$ & 0.05 \\
\hline $\mathbf{1 1 - 2 0}$ & 19 & $19 \%$ & 10 & $10 \%$ & \\
\hline $\mathbf{2 1 - 3 0}$ & 19 & $19 \%$ & 34 & $34 \%$ & \\
\hline $\mathbf{3 1 - 4 0}$ & 27 & $27 \%$ & 26 & $26 \%$ & \\
\hline $\mathbf{4 1 - 5 0}$ & 6 & $6 \%$ & 10 & $10 \%$ & \\
\hline$>\mathbf{5 0}$ & 9 & $9 \%$ & 9 & $9 \%$ & \\
\hline
\end{tabular}


Web Site: https://imed.utq.edu.iq

\begin{tabular}{|c|c|c|c|c|c|}
\hline Total & 100 & $100 \%$ & 100 & $100 \%$ & \\
\hline Mean age \pm SD & $29.08 \pm 16.46$ & & $31.8 \pm 11.2$ & \\
\hline
\end{tabular}

Table-2 Frequency distribution according to age of onset of psoriasis.

\begin{tabular}{|c|c|c|}
\hline \multirow{2}{*}{ Age of onset } & \multicolumn{2}{|c|}{ psoriasis patients (n=100) } \\
\cline { 2 - 3 } & $\mathrm{n}$ & $\%$ \\
\hline $\mathbf{1 1 0}$ & 22 & $22 \%$ \\
\hline $\mathbf{1 1 - 2 0}$ & 26 & $26 \%$ \\
\hline $\mathbf{2 1 - 3 0}$ & 23 & $23 \%$ \\
\hline $\mathbf{3 1 - 4 0}$ & 18 & $18 \%$ \\
\hline $\mathbf{4 4 0}$ & 11 & $11 \%$ \\
\hline Total & 100 & $100 \%$ \\
\hline Mean \pm SD & $24.97 \pm 15.6$ & \\
\hline
\end{tabular}

Table 3 - Frequency distributions of patient group and control group according to gender

\begin{tabular}{|c|c|c|c|c|c|}
\hline \multirow{2}{*}{ Gender } & \multicolumn{2}{|c|}{ Cases $(\mathbf{n = 1 0 0})$} & \multicolumn{2}{c|}{ Controls $(\mathbf{n = 1 0 0})$} & \multirow{2}{*}{ P value } \\
\cline { 2 - 5 } & $\mathrm{n}$ & $\%$ & $\mathrm{n}$ & $\%$ & \\
\hline Male & 51 & $51 \%$ & 60 & $60 \%$ & 0.2 \\
\hline Female & 49 & $49 \%$ & 40 & $40 \%$ & \\
\hline Total & 100 & $100 \%$ & 100 & $100 \%$ & \\
\hline
\end{tabular}

Table 4 - Frequency distributions of patient group and control group according to smoking 


\begin{tabular}{|c|c|c|c|c|c|}
\hline \multirow{2}{*}{ Smoking } & \multicolumn{2}{|c|}{ Cases $(\mathbf{n = 1 0 0})$} & \multicolumn{2}{c|}{ Controls $(\mathbf{n = 1 0 0})$} & \multirow{2}{*}{ P value } \\
\cline { 2 - 6 } & $\mathrm{N}$ & $\%$ & $\mathrm{n}$ & $\%$ & \\
\hline Smoker & 20 & $20 \%$ & 22 & $22 \%$ & 0.7 \\
\hline $\begin{array}{c}\text { Non } \\
\text { smoker }\end{array}$ & 80 & $80 \%$ & 78 & $78 \%$ & \\
\hline Total & 100 & $100 \%$ & 100 & $100 \%$ & \\
\hline
\end{tabular}

Table 5 - Frequency distributions of patient group and control group according to living

\begin{tabular}{|c|c|c|c|c|c|}
\hline \multirow{2}{*}{ Living } & \multicolumn{2}{|c|}{ Cases $(\mathbf{n = 1 0 0})$} & \multicolumn{2}{c|}{ Controls $(\mathbf{n = 1 0 0})$} & \multirow{2}{*}{ P } \\
\cline { 2 - 5 } & $\mathrm{n}$ & $\%$ & $\mathrm{n}$ & $\%$ & value \\
\hline Urban & 58 & $58 \%$ & 65 & $65 \%$ & 0.3 \\
\hline Rural & 42 & $42 \%$ & 35 & $35 \%$ & \\
\hline Total & 100 & $100 \%$ & 100 & $100 \%$ & \\
\hline
\end{tabular}

Table 6: Types of psoriasis

\begin{tabular}{|l|c|c|}
\hline type of psoriasis & $\mathbf{n}$ & $\%$ \\
\hline Psoriasis Vulgaris & 65 & $65 \%$ \\
\hline Psoriasis Guttate & 5 & $5 \%$ \\
\hline Psoriasis Pustular & 5 & $5 \%$ \\
\hline $\begin{array}{l}\text { Psoriasis Palmo } \\
\text { Plantar }\end{array}$ & 10 & $10 \%$ \\
\hline psoriasis Scalp & 15 & $15 \%$ \\
\hline Total & 100 & $100 \%$ \\
\hline
\end{tabular}

Table-7 Findings of family history, stress and infection of psoriasis patients.

\begin{tabular}{|c|c|c|}
\hline Variable & $\mathbf{n}$ & $\%$ \\
\hline Family history & 13 & $13 \%$ \\
\hline Stress & 56 & $56 \%$ \\
\hline
\end{tabular}




\section{Genotype Results}

The polymorphic of GSTM1 and GSTT1 genotypes between psoriasis patients and control group are shown in Table 8 . The ratio of GSTM1 null genotype was $63 \%$ and $49 \%$ in psoriasis patients and controls group respectively, which was no important significant $(\mathrm{OR}=0.56 ; 95 \%, \mathrm{CI}=0.32-0.99)$. The ratio of GSTT1 null genotype was high in patients $(34 \%)$ compared to controls $(20 \%)$, but we found no increase in risk of psoriasis susceptibility ( $\mathrm{OR}=0.48 ; 95 \%, \mathrm{CI}=0.25-0.92)$. Analysis of combined effect of GSTM1/GSTT1 null genotypes were found no risk of psoriasis susceptibility $(\mathrm{OR}=0.55 ; 95 \%, \mathrm{CI}=0.20-1.51)$.

Table 8.Frequency distributions of GSTM1 and GSTT1 genotype among patient and control group

\begin{tabular}{|c|c|c|c|c|c|c|}
\hline \multirow{2}{*}{$\begin{array}{c}\text { Polymorphis } \\
\text { m }\end{array}$} & \multicolumn{2}{|c|}{ Cases $(n=100)$} & \multicolumn{2}{|c|}{ Controls $(n=100)$} & \multirow[t]{2}{*}{ OR } & \multirow[t]{2}{*}{$95 \% \mathrm{CI}$} \\
\hline & $\mathrm{n}$ & $\%$ & $\mathrm{n}$ & $\%$ & & \\
\hline \multicolumn{7}{|l|}{ GSTM1 } \\
\hline Present(+) & 37 & $37 \%$ & 51 & $51 \%$ & 1 & - \\
\hline Null(-) & 63 & $63 \%$ & 49 & $49 \%$ & 0.56 & $\begin{array}{l}(0.32- \\
0.99)\end{array}$ \\
\hline \multicolumn{7}{|l|}{ GSTT1 } \\
\hline Present(+) & 66 & $66 \%$ & 80 & $80 \%$ & 1 & - \\
\hline Null(-) & 34 & $34 \%$ & 20 & $20 \%$ & 0.48 & $\begin{array}{c}(0.25- \\
0.92)\end{array}$ \\
\hline \multicolumn{7}{|l|}{$\begin{array}{c}\text { GSTM1IGS } \\
\text { TT1 }\end{array}$} \\
\hline $\begin{array}{c}\text { Present } \\
\text { Present }\end{array}$ & 27 & $27 \%$ & 40 & $40 \%$ & 1 & - \\
\hline Null \ Null & 11 & $11 \%$ & 9 & $9 \%$ & 0.55 & $\begin{array}{c}(0.20- \\
1.51) \\
\end{array}$ \\
\hline
\end{tabular}

$\mathrm{OR}=$ Odds Ratio $\quad, \quad 95 \% \mathrm{CI}=$ Confidence Interval 
Fig.1 Products of polymerase chain reaction which analyzed on 2\% agarose gel.

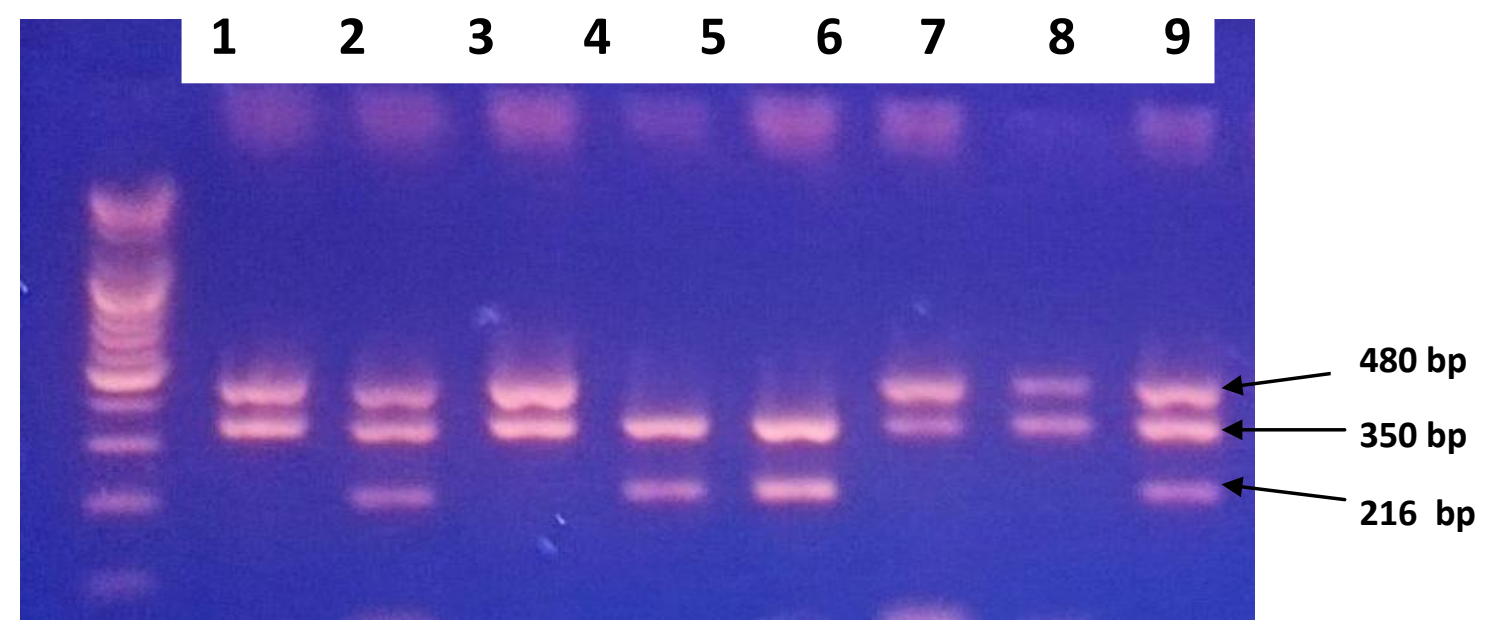

Lane 1 : DNA Ladder (2000 pb); Lane 2,4,7,8 : GSTM1 null genotype; Lane 5,6: GSTT1 null genotype; Lane 3,9 : Normal (contain both genes)

\section{Discussion}

There are few genetic and epidemiological studies on psoriasis disease in our country. In our study, we found significant differences in age between the patient and control group: mean age was $29.08 \pm 16.46$ and $31.8 \pm 11.2$ years in the patient and control group respectively $(\mathrm{P}=0.05)$, which is less compared to other studies[25,26]. Early onset $\leq 30$ years of the psoriasis disease was predominant $(71 \%)$ than the late onset $>30$ years. Similar finding suggested by Gandhi et al. [32] who found $(79.55 \%)$ of psoriasis patients had early onset of this disease. Although psoriasis was found to be more common in male $(51 \%)$, but we found no significant differences in gender between the psoriasis patients and the control group $(P=0.2)$. This finding is suggested by Gao et al. [27] whom found no significant between patient and control group according to gender $(\mathrm{P}=0.2)$. Other studies showed that disease was more common in female[28]. Although a higher

predominance of psoriasis has been explained in current smokers than nonor ex-smokers [29,30], but we found no significant between patient and 


\section{Email:utjmed@utq.edu.iq}

control group according to smoking ( $\mathrm{P}$ $=0.7)$. Psoriasis does not show significant association with living area $(\mathrm{P}=0.3)$. This is an agreement with Leyva et al [31] who found no statistical significant between psoriasis and place of residence $(\mathrm{P}=0.4)$. Psoriasis vulgaris was the most common type in present study including $65 \%$ of the total patients. This result was converged with other studies[26,28]. Family history of psoriasis ranged from 2-91\% [33,34]. In our study a positive family history was $13 \%$ of cases, which is similar with the findings of Ejaz et al. [35]who suggested $15 \%$ of cases having a firstdegree relative with psoriasis. We observed the majority of patients (56\%) were exposure to stress during lifestyle. In converged study Remröd $e t$ al [36] found (49\%) of patients of psoriasis had this disease because their exposure to a stressful during life situation. Also he found $(37 \%)$ of patients did not, and (14\%) of patients answered "don't know". In our study viral and bacterial infections were seen in $5 \%$ of cases. Other study showed $(3.25 \%)$ of psoriasis patients had viral infection[37].

Previous study demonstrated that increased oxidative stress might play an important role in the development of psoriasis[38]. The relationship between GSTs polymorphisms and psoriasis has not been clearly demonstrated. Here we investigated the association between GSTs polymorphisms and psoriasis disease.

Although the difference in the frequency of the GSTM1 null genotype between patients and controls (63\% vs. $49 \%$ ), but there was no statistically significant between patients group and controls $\quad(\mathrm{OR}=0.56 ; 95 \%, \quad \mathrm{CI}=0.32$ 0.99).Also we noticed that the GSTT1
Web Site: https://imed.utq.edu.iq

null genotype was higher in cases group (34\%) than in control group (20\%); however, it was not associated with an increased risk to development of psoriasis $(\mathrm{OR}=0.48$; $95 \%$, $\mathrm{CI}=0.25$ 0.92). Beside that the combined GSTM1 null / GSTT1 null genotype was found no increased risk of psoriasis $\quad(\mathrm{OR}=0.55 ; 95 \%, \mathrm{CI}=0.20$ 1.51).with similar finding Solak et al [25] found no association between GSTM1 and GSTT1 null genotypes and the development of psoriasis patients with Turkish ethnicity.

\section{Conclusion}

This is the first study in our country investigated the relationship between the risk of GSTM1,GSTT1 null genotype and development of psoriasis. We have noted that the GSTM1 null and GSTT1 null genotype is no associated with the development of disease in patients of Thi Qar province.

\section{References}

1. Griffiths CE, Barker JN: Pathogenesis and clinical features of psoriasis. Lancet. 2007; 370: 263-271.

2. Menter A, Gottlieb A, Feldman SR, Van Voorhees AS, Leonardi CL, Gordon KB, Lebwohl M, Koo JY, Elmets CA, et al: Guidelines of care for the management of psoriasis and psoriatic arthritis: Section 1. Overview of psoriasis and guidelines of care for the treatment of psoriasis with biologics. J Am Acad Dermatol. 2008 ; 58: 826-850.

3. Basko-Plluska JL, Petronic-Rosic V. Psoriasis: epidemiology, natural history, and differential diagnosis. 


\section{Email:utjmed@utq.edu.iq}

Psoriasis: Targets and Therapy. 2012;2:67-76.

4. Elder J, Nair R, Guo S, Henseler T, Christophers E, Voorhees J. The genetics of psoriasis. Arch Dermatol. 1994;130:216-224.

5. Elder JT, Nair RP, Henseler T, et al. The genetics of psoriasis 2001: the odyssey continues. Arch Dermatol. 2001;137:1447-1454.

6. Rahman PEJ. Genetic epidemiology of psoriasis and psoriatic arthritis. Ann Rheum Dis. 2005;64:37-39.

7. Kaur M, Sharma S, Kukreja S, Kaur J, Bassi R. Study of oxidative stress in patients of psoriasis. Int $\mathrm{J}$ Res Dermatol. 2016 ; 2:95-98.

8. Relhan V, Gupta SK, Dayal S, Pandey R, Lal H. Blood thiols and malondialdehyde levels in psoriasis. J Dermatol. 2002;29: 399-403.

9. Briganti S, Picardo M. Antioxidant activity, lipid peroxidation and skin diseases-what's new? JEADV. 2003; 17:663-9.

10. Cals-Grierson MM, Ormerod AD. Nitric oxide functions in the skin. Nitric Oxide. 2004;10(4):179-93.

11. Shindo Y, Witt E, Han D, Epstein W, Packer L. Enzymic and non-enzymic antoxidants in epidermis and dermis of human skin. J Investig Dermatol. 1994;102:122-4.

12. Langseth L. Oxidants, antioxidants and disease prevention. International Life Sciences Institute and ILSI Europe; 1995. p. 1-32.

13. Luty-Frackiwicz A, Gorka IM, Januszewska L. Influence of smoking and alcohol consumption on total antioxidant status in patients with

\section{Web Site: https://imed.utq.edu.iq}

psoriasis. Adv Clin Exp Med. 2006;15(3):463-9.

14. Baz K, Cimen MYB, Kokturk A, Yazici AC, Eskandari G, Ikizoglu $\mathrm{G}$, et al. Oxidant/antioxidant status in patients with psoriasis. Yonsei Med J. 2003;44(6):987-90.

15. Van Haaften RI, Haenen GR, Evelo CT, Bast A. Effect of vitamin E on glutathione-dependent enzymes. Drug Metab Rev. 2003;35:215-53.

16. Katoh T, Yamano Y, Tsuji M, Watanabe M. Genetic polymorphisms of human cytosol glutathione $\mathrm{S}$ transferases and prostate cancer. Pharmacogenomics. 2008;9:93-104

17. Norppa $\mathrm{H}$.Cytogenetic biomarkers and genetic polymorphisms. Toxicol Lett. 2004; 149: 309-334.

18. Okcu MF, Selvan M, Wang LE, Stout L, Erana R, et al. Glutathione Stransferase polymorphisms and survival in primary malignant glioma. Clin Cancer Res. 2004; 10: 26182625.

19. Daniel V. Glutathione Stransferases: gene structure and regulation of expression. Crit Rev Biochem Mol Biol .1993; 28: 173-207. 20. Jalood H, AL-Rikabi H, AlBadran A and Kawen A. Glutathione S-Transferase (GSTM1, GSTT1) Genes Polymorphisms Associated with Vitiligo Disease in Thi Qar Province/South of Iraq. Int.J.Curr.Microbiol.App.Sci $\quad .2016$; 5(8): 156-163.

21. Bassiouny, D.A. and Khorshied, M.M. Glutathione Stransferase M1 and T1 genetic polymorphisms in Egyption with 


\section{Email:utjmed@utq.edu.iq}

nonsegmental vitiligo. Dermatol. 2013; 38(2): 160-163.

22. Abd Rabou, F., Elserogy, H., Gheida, S., EL-Ashmawy, A. Glutathione S-Transferase Gene Polymorphisms (GSTM1 and GSTT1) in Vitiligo Patients. Life Sci. J. 2011; 8(4): 785-792.

23. Zhang J, Deng J, Zhang C, et al. Association of GSTT1, GSTM1 and CYP1A1 polymorphisms with susceptibility to systemic lupus erythematosus in the Chinese population. Clin Chim Acta. 2010 ;411: 878-81.

24. Salimi S, Nakhaee A, Jafri M, Jahantigh D, Sandooghi M, Zakeri Z,et al. Combination Effect of GSTM1, GSTT1 and GSTP1 Polymorphisms and Risk of Systemic Lupus Erythematosus. Iran J Public Health. 2015; 44 : 814-821.

25. Solak B, Karkucak M, Turan H , Ocakoğlu G, Sağ S, Yakut T, Erdem T. Glutathione S-Transferase M1 and T1 Gene Polymorphisms in Patients with Chronic Plaque-Type Psoriasis: A Case-Control Study. Med Princ Pract 2016;25:155-158.

26. Mikrani JA and Shrestha A. Clinical and Epidemiological Features of Psoriasis in Patients Visiting Lumbini Medical College. J.Lumbini. $2014 ; 2$ : 83-87.

27. Gao L, Li H, Li K, Shen Z, Liu L, LiC, Zhang Z and Liu Y. Polymorphism of the catechol-Omethyltransferase gene in Han Chinese patients with psoriasis vulgaris. Genetics and Molecular Biology. 2009; 32, 1, 32-36.

\section{Web Site: https://imed.utq.edu.iq}

28. Cakmur H, Dervis E. The relationship between quality of life and the severity of psoriasis in Turkey. Eur J Dermatol. 2015;25(2):169-76.

29. Schafer T. Epidemiology of psoriasis. Dermatology. 2006;212: 327-337.

30. Naldi L, Chatenoud L, Linder D, et al. Cigarette smoking, Body Mass Index, and stressful life events as risk factors for psoriasis: results from an Italian case-control study. J Invest Dermatol. 2005;125:61-67.

31. Leyva AM, Real AA, Carrascosa JC, Leyva IM, Sintes RN and Moleon JJ. Distribution pattern of psoriasis, anxiety and depression as possible causes of sexual dysfunction in patients with moderate to severe psoriasis. An Bras Dermatol. 2015;90(3):338-45.

32. Gandhi G, Singh Buttar B, Albert L, Hasan O and R.K. Aggarwal R.K. Psoriasis-associated genetic polymorphism in North Indian population in the CCHCR1 gene and in a genomic segment flanking the HLAC region. Disease Markers . 2011; 31: 361-370.

33. Siow KY, Safdar NA, Chong KH, Chua KB. A clinical appraisal of patients with psoriasis treated in Seremban General Hospital, Malaysia. Med J Malaysia 2004;59:330-4.

34. Marino MG, Carboni I, De Felice C, Maurici M, Maccari F, Franco E. Risk factors for psoriasis: A retrospective study on 501 outpatientsí clinical records. Ann Iq 2004;16:753-8.

35. Ejaz A, Raza N, Iftikhar N, Iftikhar A and Farooq M. Presentation of early onset psoriasis in comparison 


\section{Email:utjmed@utq.edu.iq}

comparison with late onset psoriasis: A clinical study from Pakistan .Indian J Dermatol Venereol . 2009 ; 75 : 3640.

36. Remröd C, Sjöström $\mathrm{K}$ and Svensson A . Subjective stress reactivity in psoriasis - a cross sectional study of associated psychological traits. BMC Dermatology .2015; 15:6 :2-8.

37. Alexander E, Pinto J, Pal G, Kamath $\mathrm{N}$ and Kuruvilla M. Disease
Web Site: https://imed.utq.edu.iq

concomitance in psoriasis: A clinical study of 61 cases. $2001 ; 67: 2$ : 6668.

38. Armstrong AW, Voyles SV, Armstrong EJ, et al: Angiogenesis and oxidative stress: common mechanisms linking psoriasis with atherosclerosis. $\mathbf{J}$ Dermatol Sci 2011; 63: 1-9.

\title{
GSTMI,GSTT1 وخطر الاصابة بمرض الصدفية في محافظة ذي قار
}

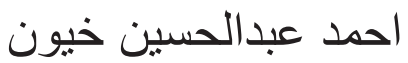

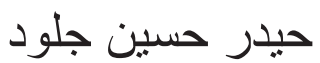

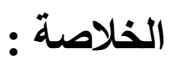

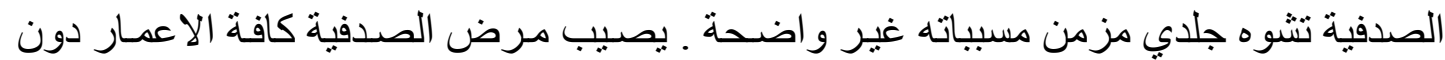

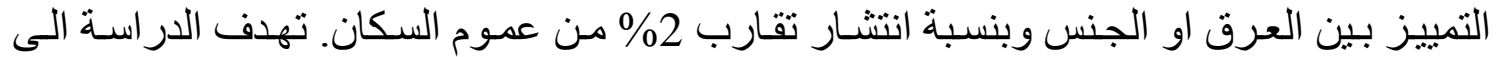

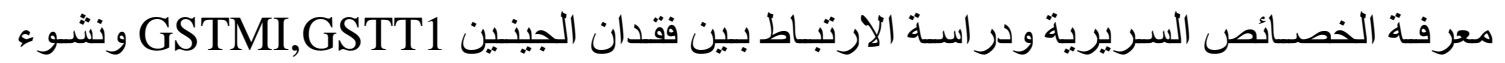

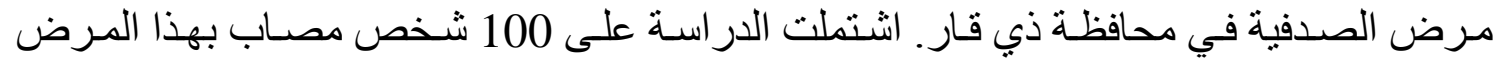

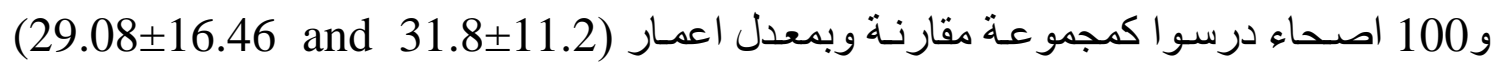

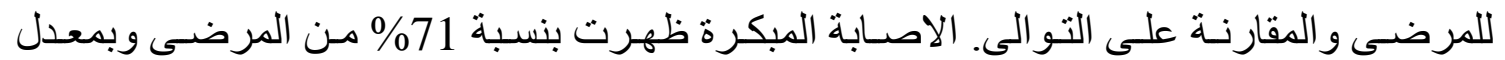

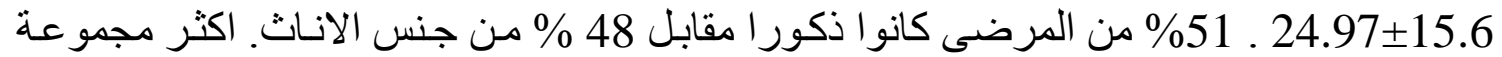

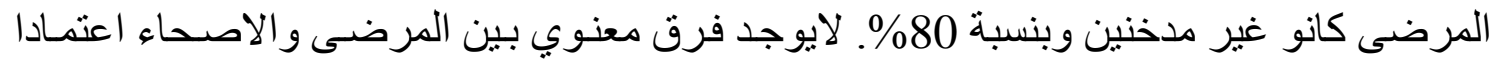

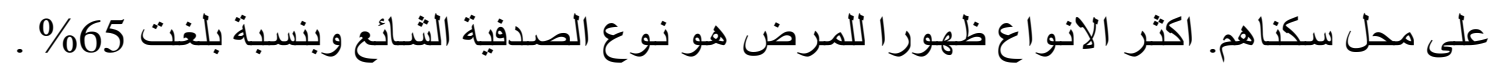
غالبية المرضى (56\%)عانو ا من اجهاد نفسي او فيزيائي اثثاء مر احل حياتهم. عند تحليل الهيل الطرز

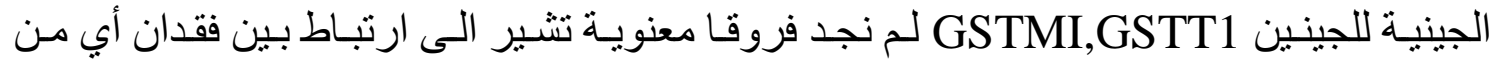
الجينين وزيادة خطر الاصابة بالصدفية(OR=0.56; 95\%, CI=0.32-0.99) و (OR=0.48) 95\%, CI=0.25-0.92 بالنسبة لجين GSTMI وجين GSTT1 على التو الى.كذلك لم نلحظ فرقا 
Thi-Qar Medical Journal (TQMJ): Vol.(13), No.(1), 2017

Email:utjmed@utq.edu.iq Web Site: $\quad$ https://jmed.utq.edu.iq

(OR=0.55; 95\% , معنويـا يدل على وجود علاقة بين فقدان الجينين معا وحدوث الصدفية

$\mathrm{CI}=0.20-1.51)$ 